\title{
Ethnobotanical survey, anthelmintic effects and cytotoxicity of plants used for treatment of helminthiasis in the Central and Kara regions of Togo
}

Essoham Ataba', Gnatoulma Katawa', Manuel Ritter², Adjoa Holali Ameyapoh¹, Kokou Anani ${ }^{1}$, Oukoe M. Amessoudji ', Pélagie Edlom Tchadié1, Tchadjabo Tchacondo', Komlan Batawila ${ }^{3}$, Yaovi Ameyapoh', Achim Hoerauf ${ }^{2,4}$, Laura E. Layland ${ }^{2,4}$ and Simplice D. Karou ${ }^{1 *}$ (1)

\begin{abstract}
Background: Traditional medicines are the main source of treatment of helminthiasis in endemic areas of Togo. The present study aimed to investigate the plants used by Traditional healers (THs) to treat helminth infections in endemic communities within the Central and Kara regions of Togo and to evaluate the anthelmintic activity of the three most cited plants.

Methods: An ethnobotanical survey was conducted from 19 to 24 June 2017 among traditional healers in the Central and Kara regions of Togo. The anthelmintic activity of the most cited plants namely Aframomum melegueta K. Schum, Khaya senegalensis A. Juss and Xylopia aethiopica A. Rich, was evaluated using microfilariae (Mf) of Litomosoides sigmodontis. The plants were evaluated for cytotoxicity according to the recommendation of NF EN ISO 10993-5 standard using the propidium iodide (PI) dye by flow cytometry on human peripheral blood mononuclear cells.

Results: A total of $197 \mathrm{THs}$ were interviewed and 41 plant species were recorded. Leguminosae (14.6\%) and Annonaceae (9.7\%) families constitute the highest number of species cited for treatment of helminth infections. Afromomum melegueta was the most cited by the THs for the treatment of onchocerciasis $(U V=0.036)$ while $X$. aethiopica was associated with the treatment of schistosomiasis $(U V=0.061)$ and lymphatic filariasis $(U V=0.061)$. There was a great agreement among the THs regarding ethnomedicinal uses of plants to treat helminthiasis with ICF values ranging from 0.57 to 0.67 . The anthelmintic assay yielded lethal doses values of $233 \mu \mathrm{g} / \mathrm{mL}, 265 \mu \mathrm{g} / \mathrm{mL}$ and $550 \mu \mathrm{g} / \mathrm{mL}$, respectively for $X$. aethiopica, A. melegueta and K. senegalensis. Afromomum melegueta and X. aethiopica presented no cytotoxicity, less than $20 \%$ death, whereas $K$. senegalensis induced moderate toxicity, $24 \pm$ $8 \%$ death.

(Continued on next page)
\end{abstract}

\footnotetext{
* Correspondence: simplicekarou@hotmail.com

'Ecole Supérieure des Techniques Biologiques et Alimentaires (ESTBA)/ Laboratoire de Microbiologie et de Contrôle de Qualité des Denrées

Alimentaires/Unité de Recherche en Immunologie et Immunomodulation (UR2IM), Université de Lomé, 01 BP 1515 Lomé, Togo

Full list of author information is available at the end of the article
}

(c) The Author(s). 2020 Open Access This article is licensed under a Creative Commons Attribution 4.0 International License, which permits use, sharing, adaptation, distribution and reproduction in any medium or format, as long as you give appropriate credit to the original author(s) and the source, provide a link to the Creative Commons licence, and indicate if changes were made. The images or other third party material in this article are included in the article's Creative Commons licence, unless indicated otherwise in a credit line to the material. If material is not included in the article's Creative Commons licence and your intended use is not permitted by statutory regulation or exceeds the permitted use, you will need to obtain permission directly from the copyright holder. To view a copy of this licence, visit http://creativecommons.org/licenses/by/4.0/ The Creative Commons Public Domain Dedication waiver (http://creativecommons.org/publicdomain/zero/1.0/) applies to the data made available in this article, unless otherwise stated in a credit line to the data. 
(Continued from previous page)

Conclusion: This study demonstrated the scientific rationale for the use of plants to treat helminthiasis in the Togolese traditional medicine. However, the use of $K$. senegalensis requires more caution since the plant is fairly toxic.

Trial Registration: NA

Keywords: Anthelmintic effects, Ethnopharmacology, Medicinal plants, Togo

\section{Background}

The emergence of resistance to anthelmintics makes it difficult to control helminth infections in endemic areas. One of the solution approaches is the search for new molecules and the development of effective therapies, affordable for low-income people, since the populations affected are leaving in developing countries. Many studies are already devoted to this, and even a new method of screening for filaricidal agents has recently been developed [1]. In this new approach, plants from the traditional pharmacopoeia have demonstrated proven anthelmintic effects [2].

Herbal medicines have been the source of many of the drugs prescribed today in modern medicine. Some examples are, aspirin from Salix alba [3], digitoxin from Digitalis [4], artemisinin from Artemisia annua [5]. Medicinal plants are precious resources in lowincome countries and more than $80 \%$ of African populations use them for health problems [6]. Therefore, the use of plant organs to heal is a question of culture and tradition in Africa [7, 8]. Understanding the properties and value of unprocessed raw medicinal plant materials is a national heritage for these countries [9]. It should be noted that for primary health care needs, a large part of the African population still turns to traditional medicine which is mainly based on herbal remedies. This is due in part to the preference and confidence of local healers over the health care system [10].

Chronic infections with helminths namely Onchocerca volvulus, Wuchereria bancrofti and Schistosoma haematobium induce diseases in endemic areas of Togo. The absence of vaccines, the constant exposure and the possibilities of reinfection with these helminths present a constant socio-economic problem and an increase in DALYs (disability-adjusted life years). Togo has an excellent biodiversity of medicinal plants used in traditional medicine for the treatment of many diseases. Thus, many traditional remedies have been developed by the practitioners of traditional medicine to treat helminth infections. However, scientific data on these herbal therapies are missing. The present study was initiated with the aim of documenting the plants usage in the treatment of helminth infections by traditional healers $(\mathrm{TH})$ in endemic communities in the Central and Kara regions of Togo and in assessing their anthelmintic and cytotoxic effects in vitro.

\section{Methods}

Study area

The ethnobotanical survey was undertaken in the Central and Kara regions of Togo (Fig. 1). Togo is a West African country boarded in the North by the Republic of Burkina Faso, the Est. by the Republic of Benin, the West by the Republic of Ghana and the South by the Atlantic Ocean. From north to south the country is organized into five economic regions: the Savannah region, the Kara region, the Central region, the Plateaux region and the Maritime region. The Central and Kara regions belong to the tropical area with a dry season from October to March and a rainy season from April to September. The annual temperatures are between 20 and $39{ }^{\circ} \mathrm{C}$, providing an excellent floristic biodiversity with numerous medicinal plants. The principal activities of the population are agriculture and trade [10].

\section{Data collection}

In total, 197 THs (136 from central region and 61 from Kara region) were interviewed from the 19th to 24th June 2017 using a structured questionnaire, after their informed consent and their agreement with a signature. The THs belong to the Tem tribe and Kabyè tribe, and all of them speak at least one local language, Kotokoli or Kabyè in which interviews were conducted. They were all members of the non-governmental organization (NGO) named "Centre d'Etude et de Recherche en Médecine Traditionnelle Appliquée du Togo” (CERMETRA) (http://tg.viadeo.com/fr/profile/cermetra.ong). CERMETRA contributes to the training and counselling of the THs on patient management and environmental preservation, mainly protecting vulnerable and endangered plant species used in traditional medicine. For example, the harvest of the leaves of Pterocarpus erinaceus which is a species included in the red list of the IUCN (https://www.iucnredlist.org/species/62027797/6202

7800), is rigorously supervised by CERMETRA after the authorisation of the forestry services to avoid the removal of vital organs such as stem bark and roots. The main activity that threatens extinction $P$. erinaceus is the exploitation of its wood, it is not really the use in 


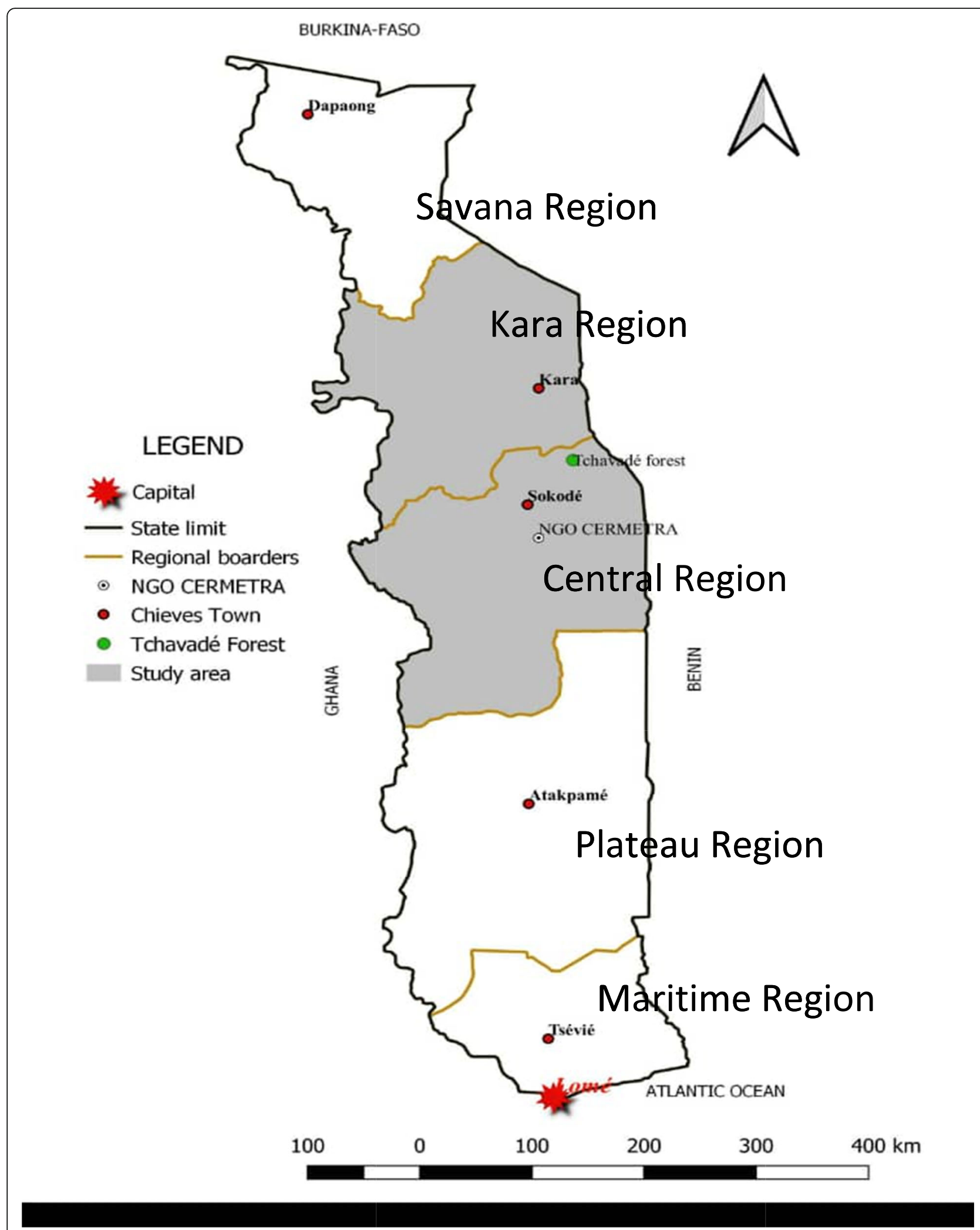

Fig. 1 Map of Togo showing the study area. The study was conducted in the Central and Kara regions of Togo. THs usually gather plant species for their medicines in the Tchavedè Forest. Various plant organs were collected for botanical identification 
traditional medicine, which moreover focuses mainly on the leaves and not the vital organs. Actions carried out in the country therefore aim to limit the exploitation of its wood and reforestation. Thus, the University of Lomé through the Faculty of Sciences is very active in revitalizing the populations of $P$. erinaceus. The University is a partner of the "South Expert Plants Sustainable Development" (SEP2D) multilateral program. The challenge of this program is to strengthen interactions and partnerships in terms of plant biodiversity between research, teaching and society's demands. In the particular case of $P$. erinaceus, proposals have been made in order to provide the elements of responses essential to the adoption of sustainable silvicultural practices which should allow a rapid reconstitution of populations in West Africa. It specifically involves (i) analyzing the biophysical and socio-cultural factors of the multiplication and domestication of $P$. erinaceus in 3 countries in West Africa (Togo, Benin and Niger), (ii) studying the variability in the structural and technological characteristics of the species' wood in relation to environmental conditions, (iii) developing a viable and large-scale production strategy for P. erinaceus plants for reforestation in West Africa and (iv) strengthen the capacities of stakeholders to regenerate and sustainably manage stands of $P$. erinaceus. http://www.sep2d.org/projets-soutenus/rechercheoperationnelle/reconstitution-peuplement-pterocarpustogo-benin-niger.

After the interview, 41 of the most commonly plant species used by THs to treat helminthiasis were collected. Since the THs often referred to these plants in a colloquial manner, samples of all 41 plants were collected with members of CERMETRA (actually THs) in the Tchavadè forest. Verification and identification of all collected plant specimens were carried out at the Botanic Laboratory of the Faculty of Sciences at the University of Lomé. Plant taxonomy was confirmed on data available from the International Plant Names Index (IPNI) website: http://www.ipni.org/. Specimen of each plants was deposited at the herbarium of the University of Lomé.

\section{Preparation of plants extracts}

All the plants materials were collected from the Tchavadè forest at Sokodé in the central Region with Traditional healers. The grains of A. melegueta, bark of $K$. senegalensis and fruits of $X$. aethiopica were washed and air-dried in laboratory at room temperature. Plant materials were reduced to powder that was used for extraction. The extraction was performed by percolation of $100 \mathrm{~g}$ powder with $500 \mathrm{~mL}$ ethanol-water (70: 30) for 48 $h$. The extract was then filtered with Whatman paper and the filtrate was evaporated until dry using a Rotary evaporator at $50{ }^{\circ} \mathrm{C}$ under reduced pressure.
To perform cytotoxicity and anthelmintic tests, 100 $\mathrm{mg} / \mathrm{mL}$ extracts were prepared by dissolving $1 \mathrm{~g}$ of dried extract in $10 \mathrm{~mL}$ distilled water. From this, serial dilutions were made and filtered using $0.45 \mu \mathrm{m}$ millipore adapted to a syringe.

\section{Purification of peripheral blood microfilariae (mf)}

Frozen Mf were obtained from the Institute for Medical Microbiology, Immunology and Parasitology, University Hospital Bonn (UKB), Bonn, Germany. The Mf for in vitro anti-microfilarial test were isolated from the peripheral blood of L. sigmodontis-infected cotton rats [11]. Blood was diluted with PBS in the ratio 1:2 and carefully loaded onto a 30-25\% Percoll gradient (Sigma-Aldrich $\mathrm{GmbH}$, Munich, Germany). After 30 min centrifugation $(300 \mathrm{~g})$ at room temperature without break, the recovered Mf were washed two times with non-supplemented RPMI-1640 medium (PAA, Linz, Austria), counted and frozen at $-80{ }^{\circ} \mathrm{C}$ in freezing medium containing $6 \%$ DMSO and $15 \%$ fetal calf serum (FCS) (PAA). For this experiment, fresh aliquots of frozen Mf were thawed and controlled for Mf viability microscopically after $2 \mathrm{~h}$ of pre-incubation at $37^{\circ} \mathrm{C}$ in RPMI- 1640 medium containing 10\% FCS in order to revitalize the microfilariae. Only aliquots with more than $95 \%$ Mf viability were used.

\section{Anthelmintic assay}

For the assay, $100 \mu \mathrm{L} /$ well of suspension containing 75 microfilariae were grown in RPMI 1640 in a 96-well plate with plant extracts 200,500 and $1000 \mu \mathrm{g} / \mathrm{mL}$. The control was a subculture without plant extract. Albendazole $(5 \mathrm{mg} / \mathrm{mL})$ was used as reference drug as previously described [2]. After 7 days incubation at $37^{\circ} \mathrm{C}$ in a humid atmosphere, the viability of the microfilariae was evaluated microscopically using trypan blue exclusion method. Living and dead Mf were counted for each concentration of drug. The concentration that induced 50\% Mf death was considered as $\mathrm{LD}_{50}$.

\section{Cytotoxicity assay}

The cytotoxicity assays was conducted according to the recommendation of NF EN ISO 10993-5 standard. Human peripheral blood mononuclear cells from healthy volunteers $(n=13)$ were isolated using ficoll density gradient centrifugation method and treated with $200 \mu \mathrm{g} / \mathrm{mL}$ plant extracts for $24 \mathrm{~h}$ at $37^{\circ} \mathrm{C}$ under $5 \% \mathrm{CO}_{2}$. Afterwards, cell pellets were harvested and stained with propidium iodide (PI) dye prior to cell acquisition using Cytoflex flow cytometer (Beckman Coulter, Brea, USA). From the lymphocytes gate, the percentage of cells expressing propidium iodide (PI) was assessed. Data were analysed using CytExpert 2.1 sofware (Beckman Coulter, Brea, USA). 


\section{Data analysis}

A Microsoft Excel spreadsheet 2013 was used to perform simple calculations and determine plant frequencies. The relative importance of species was evaluated by the frequency in which it was mentioned by the THs and a "Used value" (UV) was calculated as follows: $\mathrm{UV}=\Sigma \mathrm{U} / n$ ( $\Sigma \mathrm{U}$ is the total number of citations per species and $n$ is the number of interviewed THs. The UV is useful in determining which plants have the best use and are most often indicated in the treatment of a disease [12]. The agreement (Informant consensus factor (ICF)) of the THs regarding the uses of medicinal plants to treat helminthiasis was calculated by the following formula: $\mathrm{ICF}=\mathrm{Nuc}-\mathrm{Nt} /(\mathrm{Nuc}-$ 1) where Nuc is the number of citations for the treatment of a given disease and $\mathrm{Nt}$ is the number of species used in the treatment of a given disease [13].

Statistical analyses were performed using Graph Pad PRISM 5.02 software (GraphPad Software, La Jolla, USA). The $\chi^{2}$ test was used for the comparison between groups and the difference was considered significant with a $p$-value $<0.05$.

\section{Results}

\section{Ethnobotanical study}

\section{Characteristics of traditional healers}

A total of 197 THs were interviewed, among them 168 were men and 29 were women. $76.14 \%$ of the cohort were older than 40 years and $77.66 \%$ practiced traditional medicine for more than 10 years (Table 1 ). The majority of THs inherit the knowledge from their family according to the percentage in that category (77.16\%). According to the ethnical affiliation, the interviewed THs belonged to Tem (82.65\%), Mina (6.64\%), Moba $(8.67 \%)$ and Gourma (2.04\%) tribes.

\section{Main Helminthiasis treated by THs}

THs claimed to treat onchocerciasis, lymphatic filariasis and schistosomiasis based on observed clinical symptoms and all interviewed THs were familiar with these three helminth infections. Figure $2 \mathrm{a}$ shows the frequencies in which THs had cases and treated the associated pathologies. $43.65 \%$ of THs had treated schistosomiasis, $28.93 \%$ had treated lymphatic filariasis and $17.26 \%$ had treated onchocerciasis.
The THs recognized the disease by the main characteristics of symptoms. Figure 2 shows the list and frequencies of symptoms used by the THs to diagnose onchocerciasis, lymphatic filariasis and schistosomiasis. Itching and eye disorders were the most common symptoms associated with O. volvulus infections (Fig. 2b). Hematuria was the most obvious symptom for S. haematobium infections with nearly $70 \%$ of THs associating this symptom with the infection (Fig. 2c). Lymphatic filariasis (LF) caused by W. bancrofti was diagnosed by "big foot" (49\%) and "swelling of the foot" (36.84\%).

\section{Plants used for the treatment of Helminthiasis}

A total of 41 plant species from various families were prominently mentioned by THs during the interviews. Most belonged to Leguminosae (14.6\%) and Annonaceae (9.7\%) families and are listed in Table 2.

According to the UV score, A. melegueta, X. aethiopica and $K$. senegalensis were the most frequently used for the treatment of onchocerciasis, schistosomiasis and lymphatic filariasis. A. melegueta was the most cited by the THs for the treatment of onchocerciasis (UV= 0.036) while $X$. aethiopica was associated with the treatment of schistosomiasis (UV $=0.061)$ and lymphatic filariasis $(\mathrm{UV}=0.061)$. Moreover, A. melegueta, $X$. aethiopica and $K$. senegalensis were also more used for the treatment of inflammation ( $\mathrm{UV}=0.066$, UV $=0.056$ and $\mathrm{UV}=0.025$ respectively, data not shown). The agreement among the THs for treating a given disease with plant materials was high with 0.57 for onchocerciasis, 0.66 for lymphatic filariasis and 0.61 for schistosomiasis.

Roots, seeds, leaves and barks were the main plant's organs used by THs to prepare their medicinal recipes respectively, 35, 24, 21 and 14\% (Fig. 3a). All the interviewed THs claimed to harvest plant materials during any season and at any time of the day.

For the formulation of medicinal recipes, powder (36.17\%) and decoction (34.04\%) were most cited (Fig. $3 \mathrm{~b})$. In addition, it was observed that most of the THs administrated the preparation by oral $(51.06 \%)$ or topical $(63.83 \%)$ routes.

\section{Anthelmintic effects}

In the anthelmintic assay, the microfilariae from the control subculture, without drug were not stained, while

Table 1 Characteristics of THs treating Helminthiasis

\begin{tabular}{|c|c|c|c|c|c|c|c|c|c|}
\hline & \multirow{2}{*}{$\begin{array}{l}\text { Gender } \\
\mathbf{N}(\%)\end{array}$} & \multicolumn{2}{|l|}{ Age $\boldsymbol{N}(\%)$} & \multicolumn{3}{|c|}{ Experience $\boldsymbol{N}(\%)$} & \multicolumn{3}{|c|}{ Origin of the knowledge $\boldsymbol{N}(\%)$} \\
\hline & & $<40$ years & $\geq 40$ years & $0-4$ years & $5-9$ years & $\geq 10$ years & Heritage & Training & Calling \\
\hline Men & $168(85.28)$ & $38(80.85)$ & $130(8.67)$ & 10(55.56) & $22(84.62)$ & 136(88.89) & $133(67.51)$ & $21(10.66)$ & 14(07.10) \\
\hline Women & $29(14.72)$ & $9(19.15)$ & $20(13.33)$ & $8(44.44)$ & $4(15.38)$ & $17(11.11)$ & 19(9.64) & $9(04.57)$ & $1(0.51)$ \\
\hline Total & $197(100)$ & $47(23.86)$ & 150(76.14) & 18(9.14) & $26(13.20)$ & 153(77.66) & 152(77.16) & $30(15.22)$ & $15(7.61)$ \\
\hline
\end{tabular}




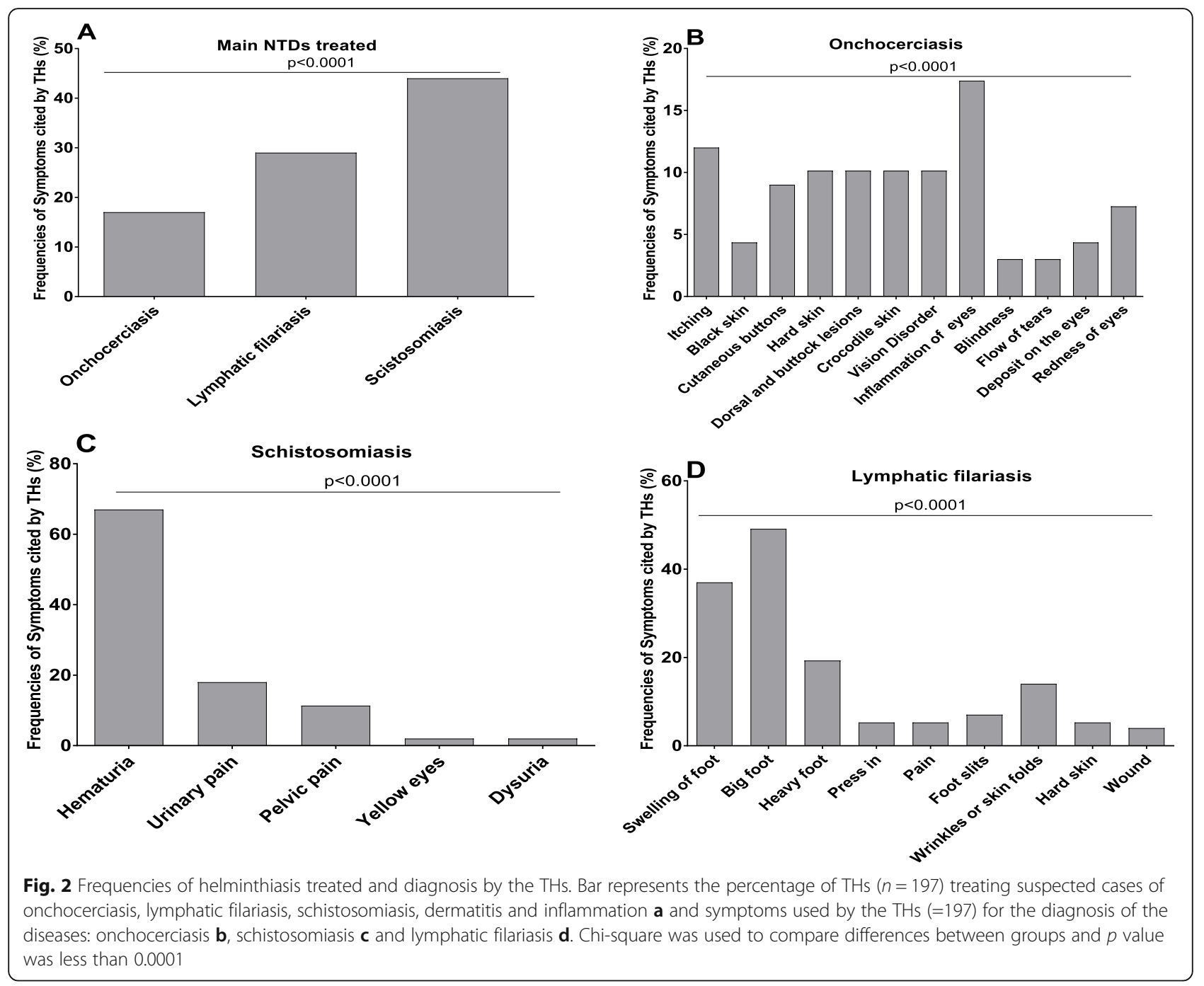

microfilariae from Albendazole, A. melegueta, K. senegalensis and $X$. aethiopica, subculture were stained blue in the presence of trypan blue (Fig. 4). This indicated that A. melegueta, $K$. senegalensis and $X$. aethiopica had induced microfilariae death. The concentration that induced the death of $50 \%$ of microfilariae was $233 \mu \mathrm{g} / \mathrm{mL}$ for X. aethiopica, $265 \mu \mathrm{g} / \mathrm{mL}$ for A. melegueta and $550 \mu \mathrm{g} / \mathrm{mL}$ for $K$. senegalensis (Fig. 4).

\section{Cytotoxicity}

The cytotoxicity of the plants was evaluated by flow cytometry using PI staining after PBMCs were cultured with the plant extracts. According to the NF EN ISO 10993-5 standards classification, A. melegueta and $X$. aethiopica plant extracts were not cytotoxic. This was indicated by less than $20 \%$ of $\mathrm{CD} 4{ }^{+} \mathrm{PI}^{+}$cells. It was however observed that $K$. senegalensis induced moderate cell toxicity $(24 \pm 8 \%$ of $\mathrm{CD}^{+} \mathrm{PI}^{+}$cells) (Fig. 5).

\section{Discussion}

This study aimed to document the use of plants in the treatment of helminthiasis, the survey revealed that male THs were more represented contrary to the reports of Gale et al. who found that women in Togo were more represented in complementary and alternative medicine [14]. The reason could be linked to cultural issues in the study region, since women retain a more traditional role as homeworkers. The findings however were in accordance with other study that showed the predominance of men among TH in Tem tribe [10]. The majority of THs were over 40 years old and had more than 10 years professional experience in traditional medicine. Most of them inherited their knowledge from their family confirming previous findings in this region [15]. To diagnose the disease, the THs rely on symptoms. Characteristic symptoms of lymphatic filariasis are hydrocele and lymphedema [16]. The diagnosis of urinary schistosomiasis should be especially suspected in cases of terminal hematuria and eosinophilia. It can be 


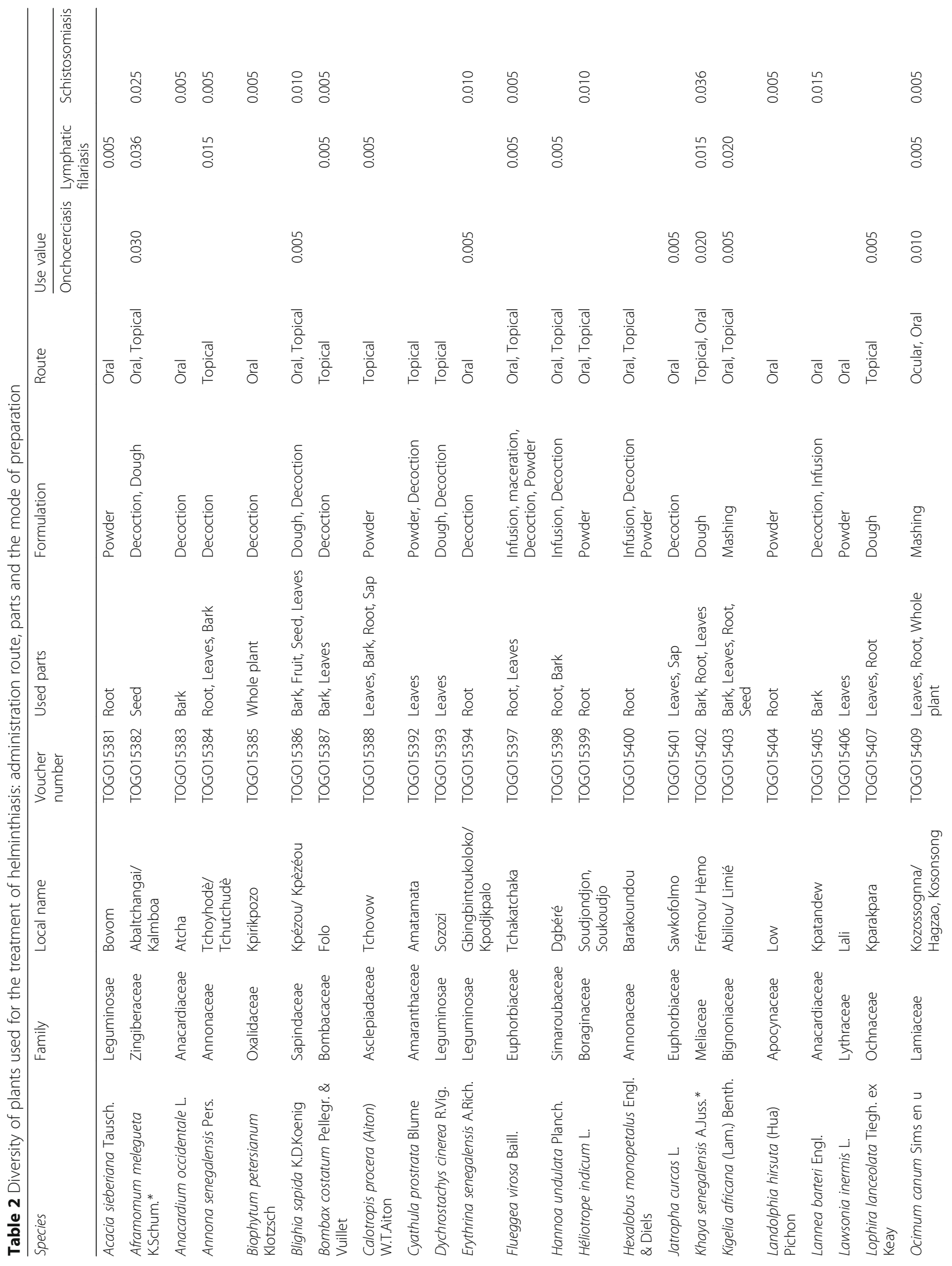




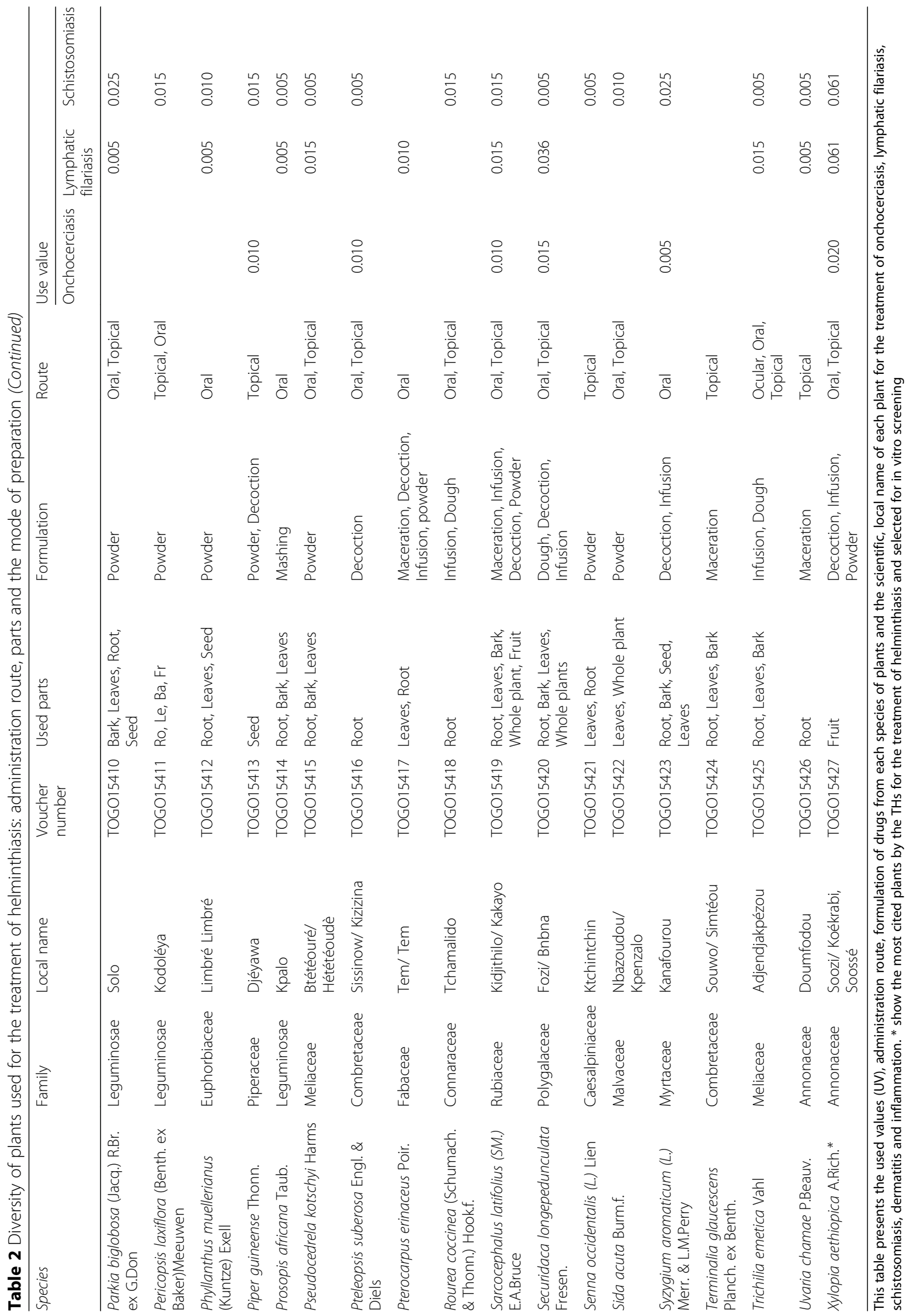




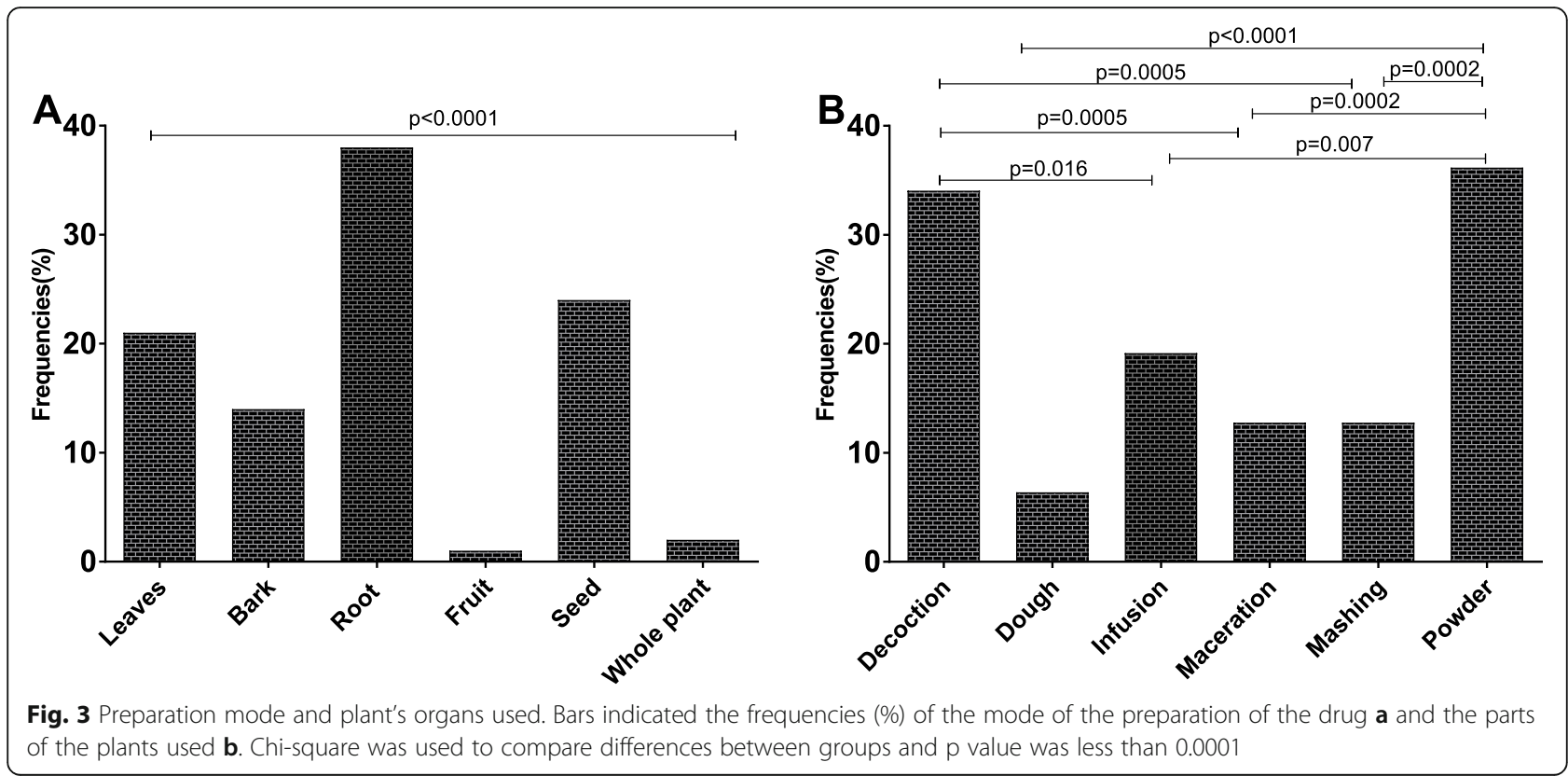

considered that the interviewed THs have a basic knowledge of the target diseases because they can recognize most of the specific symptoms [17].

Some plant families seem to stand out in any pharmacopoeia. A study on antimalarial plants in the Maritimes region of the same country revealed that out of 52 antimalarial plants species, Rubiaceae and Rutaceae were the most used to combat malaria [18]. In a study conducted in the central plate of Burkina Faso, the following families Caesalpiniaceae, Poaceae, Mimosaceae and Fabaceae have been ranked amongst the richest in species citations [19]. These medicinal plants were distributed among 28 families, the largest proportion belonging to the families Fabaceae and Anacardiaceae. Telefo et al. also identified 46 plant species belonging to 26 families, the largest number of species recorded in Asteraceae and Acanthaceae [20]. In this study, 41 species were recorded and the largest number of species belonged to Leguminosae and Annonacea. The preference for their use may be related to their accessibility, as they are common and grow more in this area. According to Heinrich et al., when the consensus factor of informants is high, it reflects a good knowledge of medicinal plants, a collective knowledge of their uses, but also an exchange of information between THs [21]. In the study the ICF was high meaning that there was a great agreement among the THs regarding the use of these plants for the treatment of helminthiasis. Many authors studied the anthelmintic properties of plants in Africa [22]. Several plants used in the treatment of helminthiasis were found active in in vitro screenings. For examples Ceratonia siliqua extract was shown to ameliorate Schistosoma mansoni-induced liver fibrosis, while Verbascum sinaiticum and Commiphora swynnertonii exerted trypanocidal activity [23, 24]. Anthelmintic effects of A. melegueta on helminth parasites, were observed by Akinsanya et al. [25]. The ethanolic extract of A. melegueta also known as "grain of paradise" has antiinflammatory properties by inhibiting the activity of cyclooxygenase-2 (COX-2) enzyme [26]. A. melegueta seeds are also used in Africa to treat diarrhoea and gastroenteritis [27]. In southern Nigeria, Benin and Togo, it is employed in divine practices [28]. Xylopia aethiopica was mostly used for the treatment of filariasis and schistosomiasis [29]. The plant is also used commonly in Nigeria by traditional herbalists to treat gastrointestinal helminth parasites [30]. Ademola et al. suggested the use of $K$. senegalensis extract in anthelmintic therapy in veterinary practice [31]. Antitrypanosomal activity of $K$. senegalensis was also investigated by some authors [32]. In the present study, in vitro anthelmintic activities of the three plants was investigated using microfilariae of Litomosoides sigmodontis at different concentrations of the plant extracts. The mortality of Mf was dose-dependent and X. aethiopica had more effect on the microfilariae indicated by the lowest $L D_{50}$. These data justify the use of the cited plants by the THs for the treatment of helminthiasis. Further studies on the effect of these plants on parasite paralysis and mobility should be carried on.

Fruit extracts are used to treat coughs, bronchitis, dysentery rheumatism and malaria [33-35]. The study showed that root, leaves and seed were the parts of the plants most cited by the THs for the treatment of helminthiasis. Previous studies have shown that leaves and roots were mostly used for the treatment of asthma [36]. 


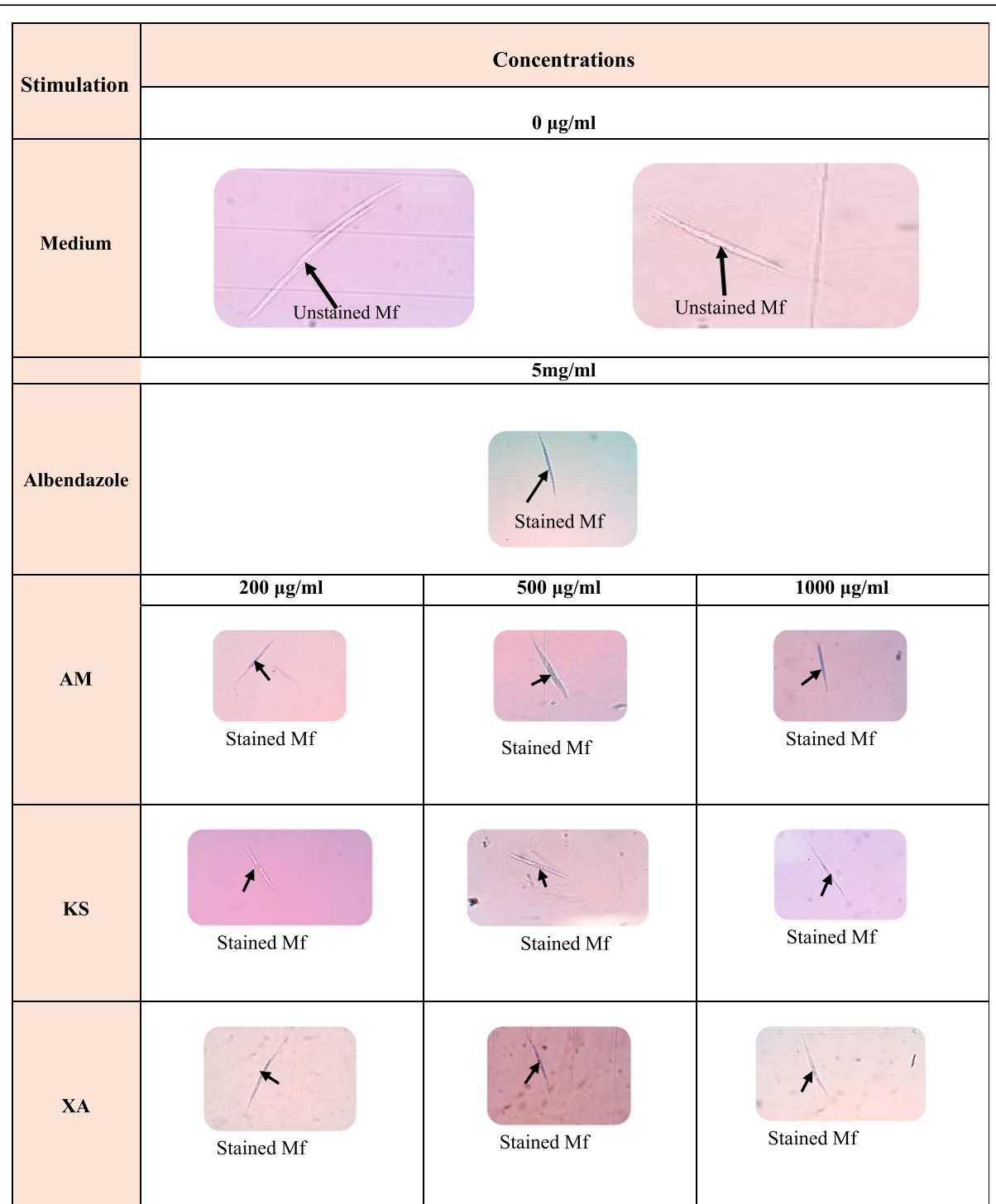

Fig. 4 Anthelmintic effect of Xylopia aetiopica (XA), Aframomum melegueta (AM) and Khaya senegalensis (KS) on microfilariae (Mf) of Litomosoides sigmodontis. Mf ( $n=75 /$ well) of Litomosoides sigmodontis were cultured in absence of plant extracts $(0 \mu \mathrm{g} / \mathrm{ml}$, medium) or in presence of AM (green line), KS (blue line) and XA (red line) at different concentrations $(200 \mu \mathrm{g} / \mathrm{ml}, 500 \mu \mathrm{g} / \mathrm{ml}$ and $1000 \mu \mathrm{g} / \mathrm{ml})$. After 7 days culture, the viability of microfilariae were evaluated using typan blue. Graph shows the percentage of dead Mf for each concentration. The concentration that induced $50 \%$ of death was designed lethal dose 50 (LD50)

A similar study showed that to treat liver disease, the most used parts of this plant were the leaves and roots, thus extracts of this plant can aid in a broad spectrum of symptoms [37].

The cytotoxicity of the three studied plants by the THs to treat helminthiasis was evaluated on human peripheral mononuclear blood cells (PBMCs) by flow cytometry. This method has the advantage to directly show the toxicity of the plant for human cells but an in vivo evaluation could indicate exactly which vital organs are damaged. Afromomum melegueta and X. aethiopica were not cytotoxic at $200 \mu \mathrm{g} / \mathrm{mL}$ but $K$. senegalensis revealed moderate toxicity with cell mortality above $20 \%$ at the same concentration. Many studies were performed on the cytotoxicity of the three extracts. Sahar et al, showed that $K$. senegalensis would be toxic to human liver, breast and colon cancer cells with $\mathrm{IC}_{50}$ of $61.1,79.7$, and $61 \mu \mathrm{g} / \mathrm{mL}$ respectively and sesquiterpens occurring in the plant would be responsible for its toxicity [38]. On the other hand, Idoh et al. revealed that A. melegueta has a hepatoprotective effect on rats [29]. Apart from its hepatoprotective property, A. melegueta would also have anti-apoptotic properties [39]. Similarly, volatile oil from $X$. aethiopica was found to be non-toxic to human epidermal cells line [40]. 

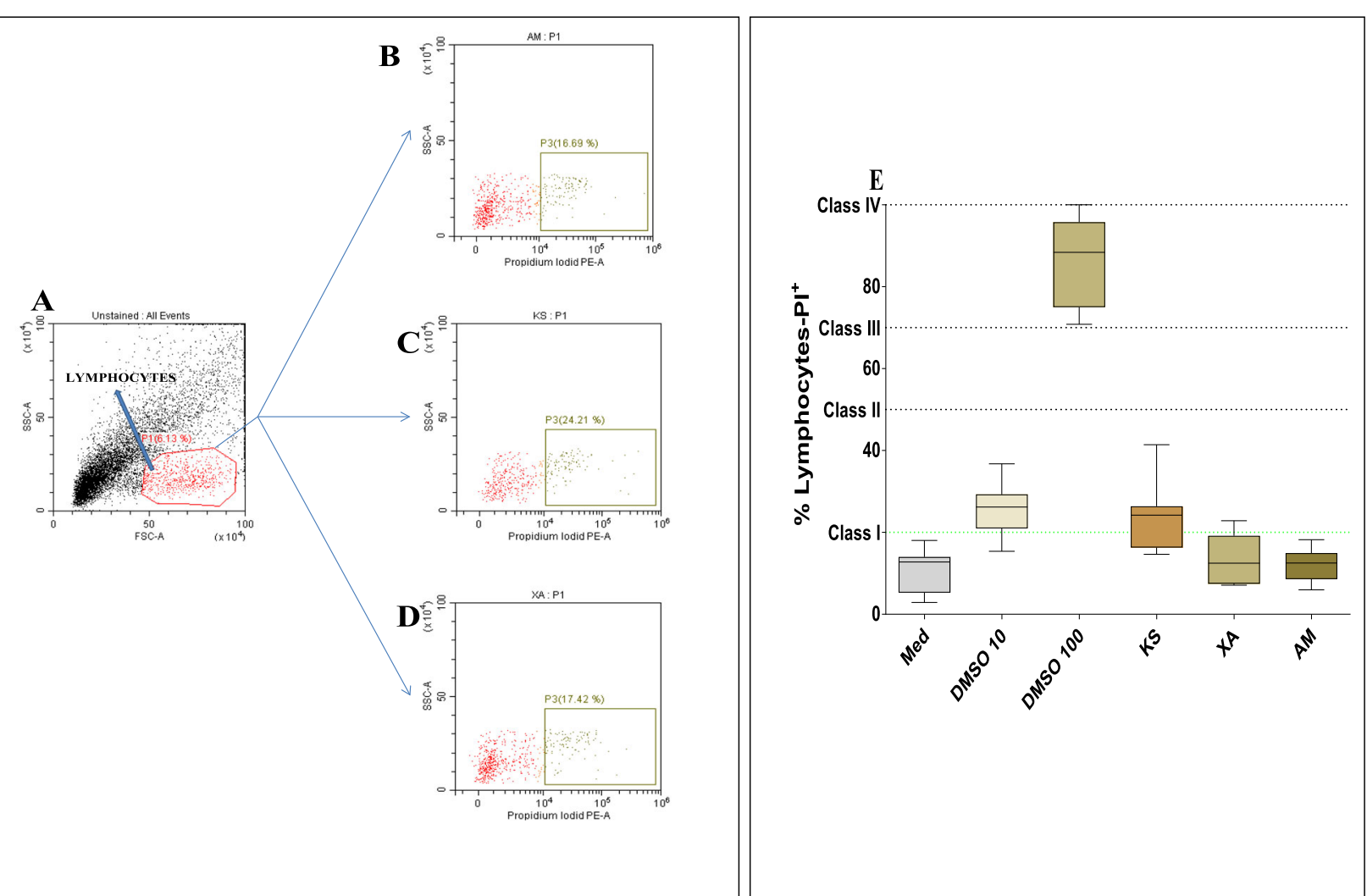

Fig. 5 Cytotoxicity of the most frequently used plants by the THs for the treatment of helminthiasis: Human PBMCs $\left(2 \times 10^{5}\right.$ cells/well) were left alone (Med) or stimulated with $200 \mathrm{\mu g} / \mathrm{ml}$ of AM, KS, XA, DMSO 100 and $10 \%$ for $24 \mathrm{~h}$. Cells were stained with propidium iodide dye (PI) and acquired by flow cytometry. $\mathbf{a}$ : lymphocytes gate, $\mathbf{b}, \mathbf{c}$, and $\mathbf{d}$ are $\mathrm{Pl}^{+}$cells in presence of AM, KS and XA respectively. (E) Box whiskers (tukey) with outliers show the percentage of lymphocytes expressing PI $(n=13)$. $P$ values were determined by Mann-Whitney U-test. The NF EN ISO 10993-5 standards classifications were indicated by class I (not cytotoxic), class II (moderate cytotoxicity), class III (Benign cytotoxicity) and class IV (severe cytotoxicity)

Many studies have demonstrated the anthelmintic effects of total phenolic and flavonoids compounds [41-44]. However, it would be difficult to say with accuracy, that these chemical groups are responsible for the activity observed in the present study. Thus, further bioguided fractionation of each plant should be undertaken to identify the active principles.

\section{Conclusion}

This study demonstrated that THs had knowledge about the treatment of helminthiasis based on plants materials and highlighted the main plants used in the Central and Kara region of Togo. The anthelmintic and cytotoxicity effects of these commonly used plants were delineated. The benefits of listening to THs in such endemic areas is paramount to unveil potential new sources for fighting helminthiasis in general and moreover, contribute to the identification of new molecules for the treatment of symptoms and conditions arising from chronic helminth infections.

\section{Abbreviations}

AM: Aframomum melegueta; CD4: Cluster of Differenciation Antigen 4; CERMETRA: Centre d'Etude et de Recherche en Médecine Traditionnelle Appliquée du Togo; $\mathrm{CO}_{2}$ : Carbon Dioxide; COX-2: Cyclooxygenase-2; DALYs: Disability-Adjusted Life Years; DMSO: Dimethyl Sulfoxide; EN: European Norm; FCS: Fetal Calf Serum; IC50: The half maximal inhibitory concentration; ICF: Informant Consensus Factor; IPNI: International Plant Names Index; ISO : International Organization for Standardization; KS: Khaya senegalensis; LD50: Median Lethal Dose; LF: Lymphatic filariasis; Mf: Microfilariae; NF : Norme Française; NGO: Non-Governmental Organization; Nt: Number of species used in the treatment of a given disease; Nuc: Number of citations for the treatment of a given disease; PBMCs: Peripheral Blood Mononuclear Cells; PBS : Phosphate-buffered saline; PI: Propidium lodide; RPMI: Roswell Park Memorial Institute medium; THs: Traditional Healers; UV: Used Value; XA: Xylopia aethiopica; CBRS: Comité de Bioéthique pour la Recherche en Santé

\section{Acknowledgments}

We thank all of the traditional healers from the NGO CERMETRA for participating in the study and sharing their knowledge.

\section{Authors' contributions}

EA, GK, AHA, PET and OMA contributed to design the survey tool, carried out the survey and in vitro tests. GK, MR, LEL, AH and SDK designed the study protocol, analyzed, interpreted and validated all the data. KB, YA and TT contributed to the identification of the plants. GK, SDK and LEL wrote the paper which was then read and approved by all other authors. 


\section{Funding}

This work was funded through grants awarded to GK and LEL from the German Research Foundation (DFG; Grant LA2746/1-1) within the "GermanAfrican Cooperation Projects in Infectiology". In addition, AH is financially supported by the Federal Ministry of Education and Research (BMBF; initiative Research Networks for Health Innovations in sub-Saharan Africa: TAKeOFF) and is a member of the Excellence Cluster Immunosensation (DFG, EXC 1023). LEL and AH are also members of the German Center of Infectious Disease (DZIF)

\section{Availability of data and materials}

The datasets during and/or analysed during the current study available from the corresponding author on reasonable request.

\section{Ethics approval and consent to participate}

The study has the authorisation code N043/2016/MSPS/CAB/SG/DPLET/CBRS from the ethical board "Comité de Bioéthique pour la Recherche en Santé (CBRS)" of the Ministry of Health in Togo. The THs and healthy blood donors gave their informed consent and certifying their agreement with a signature (signed forms are available).

\section{Consent for publication}

Not Applicable.

\section{Competing interests}

The authors declare that they have no competing interests.

\section{Author details}

${ }^{1}$ Ecole Supérieure des Techniques Biologiques et Alimentaires (ESTBA)/ Laboratoire de Microbiologie et de Contrôle de Qualité des Denrées Alimentaires/Unité de Recherche en Immunologie et Immunomodulation (UR2IM), Université de Lomé, 01 BP 1515 Lomé, Togo. ${ }^{2}$ Institute for Medical Microbiology, Immunology and Parasitology (IMMIP), University Hospita Bonn (UKB), Bonn, Germany. ${ }^{3}$ Laboratoire de Biologie et Ecologie Végétale, Faculté des Sciences (FDS), Université de Lomé, Lomé, Togo. ${ }^{4}$ German Center for Infection Research (DZIF), partner site Bonn-Cologne, Bonn, Germany.

Received: 23 March 2020 Accepted: 26 June 2020

Published online: 07 July 2020

\section{References}

1. Fombad FF, Njouendou AJ, Ndongmo PC, Ritter M, Chunda VC, Metuge HM, et al. Effect of flubendazole on developing stages of Loa loa in vitro and in vivo: a new approach for screening filaricidal agents. Parasit Vectors. 2019; 12(1):14

2. Swargiary A, Daimari A, Daimari M, Basumatary N, Narzary E. Phytochemicals, antioxidant, and anthelmintic activity of selected traditional wild edible plants of lower Assam. Indian J Pharmacol. 2016;48(4):418-23.

3. Vane J, Botting R. Aspirin and other salicylates. London: Chapman and hall; 1992.

4. Kreis W, May U, Reinhard E. UDP-glucose: Digitoxin 16'-O-glucosyltransferase from suspension cultured Digitalis lanata cells. Plants Cell Rep. 1986:5:442-5.

5. Miller Louis H, Su X. Artemisinin: discovery from the Chinese herbal garden. Cell. 2011:146(6):855-8.

6. Jiofack T, Fokunang C, Guedje N, Kemeuze V, Fongnzossie E, Nkongmeneck BA, et al. Ethnobotanical uses of medicinals plants of two ethnoecological regions of Cameroon. Int J Med Medi Sci. 2010;3(2):60-79.

7. Jouad H, Haloui M, Rhiouani H, El-Hilaly J, Eddouks M. Ethnopharmacological survey of medicinal plants used for treatment of diabetes, cardiac and renal disease in the North Center region of Morocco. J Ethnopharmacol. 2001;115:175-82.

8. Kokou K, Tossou G, Essou J-P, Batawila K, Akoegninou A, Akpagana K. Biodiversité médicinale au sud du Togo. J Rech Sci Univ Bénin (Togo). 2001 5(1):7.

9. Salhi S, Fadli M, Zidane L, Douira A. Floristic and ethnobotanical study of medicinal plants of Kénitra (Maroc). Lazaroa. 2010;31:133-46.

10. Karou DS, Tchacondo T, Agassounon Djikpo Tchibozo M, Abdoul-Rahaman S, Anani K, Koudouvo K, et al. Ethnobotanical study of medicinal plants used in the management of diabetes mellitus and hypertension in the centra region of Togo. Pharm Biol. 2011;49(12):1286-97.
11. Chandrashekar R, Rao UR, Rajasekariah GR, Subrahmanyam D. Separation of viable microfilariae free of blood cells on Percoll gradients. J Helminthol. 1984;58(1):69-70. Zhang X. Regulatory situation of herbal medicines. A worldwide review (WHO/trm/981). 1998.

12. Guinnin DF, Sacramento TI, Sezan A, Ategbo J. Etude Ethnobotanique des plantes médicinales utilisées dans le traitement traditionnel des hépatites virales $B$ et $C$ dans quelques départements du Bénin. Int J Biol Chem Sci. 2015;9(3):1354-66.

13. Korbmacher F, Komlan K, Gantin RG, Poutouli WP, Padjoudoum K, Karabou $P$, et al. Mansonella perstans, Onchocerca volvulus and Strongyloides stercoralis infections in rural populations in central and southern Togo. Parasite Epidemiol Control. 2018;3(2):77-87.

14. Gale N. The sociology of traditional. Complement Alt Med Soc Compass. 2014;8(6):805-22.

15. Reyes-García V, Broesch J, Calvet-Mir L, Fuentes-Peláez N, McDade TW, Parsa S, et al. Cultural transmission of ethnobotanical knowledge and skills: an empirical analysis from an Amerindian society. Evol Hum Behav. 2009;30(4): 274-85.

16. Arndts K, Deininger S, Specht S, Klarmann U, Mand S, Adjobimey T, et al. Elevated adaptive immune responses are associated with latent infections of Wuchereria bancrofti. PLoS Negl Trop Dis. 2012;6(4):e1611.

17. Utzinger J, Becker S, Knopp S, Blum J, Neumayr, A. L, Keider J, et al. Neglected tropical diseases: Diagnosis, clinical management, treatment and control. Eur J Med Sci 142:w13727. 2012.

18. Koudouvo K, Karou D, Kokou K, Essien K, Aklikokou K, Glitho I. An ethnobotanical study of antimalarial plants in Togo maritime region. J Ethnopharmacol. 2011;134:183-90.

19. Nadembega P, Boussim J, Nikiema J, Poli F, Antognoni F. Medicinal plants in Baskoure, Kourittenga Province, Burkina Faso: an ethnobotanical study. J Ethnopharmacol. 2011:133:378-95.

20. Telefo P, Lienou L, Yemele M, Lemfack M, Mouokeu C, Goka C. Ethnopharmacological survey of plants used for the treatment of female infertility in Baham, Cameroon. J Ethnopharmacol. 2011;136:178-87.

21. Heinrich M, Ankli A, Frei B, Weimann C, Sticher O. Medicinal plants in Mexico: Healer's consensus and cultural importance. Soc Sci Med. 1998;47: 1859-71.

22. Koné WM, Atindehou KK, Dossahoua T, Betschart B. Anthelmintic activity of medicinal plants used in northern Côte d'lvoire against intestinal Helminthiasis. Pharm Biol. 2005;43(1):72-8.

23. Al-Olayan EM, El-Khadragy MF, Alajmi RA, Othman MS, Bauomy AA, Ibrahim SR, et al. Ceratonia siliqua pod extract ameliorates Schistosoma mansoniinduced liver fibrosis and oxidative stress. BMC Complement Alter Med. 2016;16(1):434

24. Mergia E, Shibeshi W, Terefe G, Teklehaymanot T. Antitrypanosomal activity of Verbascum sinaiticum Benth. (Scrophulariaceae) against Trypanosoma congolense isolates. BMC Complement Altern Med. 2016;16(1):362.

25. Nagagi YP, Silayo RS, Kweka EJ. Trypanocidal activity of ethanolic extracts of Commiphora swynnertonii Burtt on Trypanosoma congolense. BMC Complement Altern Med. 2016:16:195

26. Akinsanya B, Utoh OU, Ukwa UD. Toxicological, phytochemical and anthelmintic properties of rich plant extracts on Clarias gariepinus. J Basic Appl Zool. 2016;74:75-86.

27. Ilic NM, Dey M, Poulev AA, Logendra S, Kuhn PE, Raskin I. Anti-inflammatory activity of grains of paradise (Aframomum melegueta Schum) extract. J Agric Food Chem. 2014;62(43):10452-7.

28. Jiofack T, Fokunang C, Kemeuze V, Fongnzossie E, Tsabang N, Nkuinkeu R, et al. Ethnobotany and phytopharmacopoea of the south-west ethnoecological region of Cameroon. J Med Plants Res. 2008;2(8):197-206.

29. Idoh K, Karou D, Agbonon A, Adjrah Y, Gbeassor M. Effect of Aframomum melegueta on carbon tetrachloride induced liver injury. J Appl Pharm Sci. 2013;3(09):098-102.

30. Oloyede A, Aduramigba-Modupe A. Antimicrobial activities of crude ethanolic extract of Xylopia aethiopica. Int J Curr Res. 2011;3(10):5-7.

31. Suleiman MM, Mamman M, Aliu YO, Ajanusi JO. Anthelmintic activity of the crude methanol extract of Xylopia aethiopica against Nippostrongy/us brasiliensis in rats. Veterinarski Arhiv. 2005:75:487-95.

32. Ademola IO, Fagbemi BO, Idowu SO. Evaluation of the anthelmintic activity of Khaya senegalensis extract against gastrointestinal nematodes of sheep: in vitro and in vivo studies. Vet Parasitol 2004;122(2):151-164.

33. Ibrahim MA, Musa AM, Aliyu AB, Mayaki HS, Gideon A, Islam MS. Phenolicsrich fraction of Khaya senegalensis stem bark: antitrypanosomal activity and 
amelioration of some parasite-induced pathological changes. Pharm Biol. 2013;51(7):906-13.

34. Soh D, Nkwengoua E, Ngantchou I, Nyasse B, Denier C, Hannaert V. Xylopioxyde and other bioactive kaurane-diterpenes from Xylopia aethiopica Dunal (Annonaceae). J Appl Pharm Sci. 2013;3(12):013-9.

35. Burkill H. The useful plants of West Tropical Africa. Families JL Kew: Royal Botanic Gardens, Kew xi,3:857. 1995.

36. Woode E, Ameyaw E, Boakye-Gyasi E, Abotsi W. Analgesic effects of an ethanol extract of the fruits of Xylopia aethiopica (Dunal) A. Rich (Annonaceae) and the major constituent, xylopic acid in murine models. J Pharm Bioallied Sci. 2012;4(4):291-301.

37. Gbekley HE, Katawa G, Karou SD, Anani S, Tchadjobo T, Ameyapoh Y, et al. Ethnobotanical study of plants used to treat asthma in the maritime region in Togo. Afr J Tradit Complement Altern Med. 2017;14(1):196-212.

38. Kpodar MS, Karou SD, Katawa G, Anani K, Gbekley HE, Adjrah Y, et al. An ethnobotanical study of plants used to treat liver diseases in the maritime region of Togo. J Ethnopharmacol. 2016;181:263-73.

39. Sahar SES, Elsayed AA, Amal AM, Fatma AH. Volatile constituents and cytotoxic activity of Khaya grandifoliola and Khaya senegalensis flower extracts. Int J Geogr Inf Syst 2016;22:2:183-189.

40. El-Halawany AM, El Dine RS, El Sayed NS, Hattori M. Protective Effect of Aframomum melegueta phenolics Against CCl4-Induced Rat Hepatocytes Damage; Role of Apoptosis and Pro-inflammatory Cytokines inhibition Sci Rep 2014:4(5880).

41. Koba K, Sanda K, Raynaud C, Guyon C, Chaumont J, Nicod L. Chemical composition and In Vitro cytotoxic activity of Xylopia aethiopica (Dun) A. Rich. (Annonaceae) fruit essential oil from Togo. J Essent Oil Res. 2008;20(4):354-7.

42. Akter KN, Karmakar P, Das A, Anonna SN, Shoma SA, Sattar MM. Evaluation of antibacterial and anthelmintic activities with total phenolic contents of Piper betel leaves. Avicenna J Phytomed. 2014;4(5):320-9.

43. Aremu AO, Ndhlala AR, Fawole OA, Light ME, Finnie JF, Van Staden J. Pharmacological evaluation and phenolic content of ten south African medicinal plants used as anthelmintics. S Afr J Bot. 2010;76(3):558-66.

44. Jiang B, Chi C, Fu Y-W, Zhang Q-Z, Wang G-X. In vivo anthelmintic effect of flavonol rhamnosides from Dryopteris crassirhizoma against Dactylogyrus intermedius in goldfish (Carassius auratus). Parasitol Res. 2013;112(12):4097-104.

\section{Publisher's Note}

Springer Nature remains neutral with regard to jurisdictional claims in published maps and institutional affiliations.

Ready to submit your research? Choose BMC and benefit from:

- fast, convenient online submission

- thorough peer review by experienced researchers in your field

- rapid publication on acceptance

- support for research data, including large and complex data types

- gold Open Access which fosters wider collaboration and increased citations

- maximum visibility for your research: over $100 \mathrm{M}$ website views per year

At $\mathrm{BMC}$, research is always in progress.

Learn more biomedcentral.com/submissions 